\title{
Investigation of the transient state of oxidation-chloridation
}

\author{
E. Reese, E.M. Müller-Lorenz and H.J. Grabke
}

Max-Planck-Institut für Eisenforschung $\mathrm{GmbH}$, Abteilung Physikalische Chemie, Max-PlanckStr. 1, 4000 Düsseldorf, Germany

\begin{abstract}
The transient state of the simultaneous oxidation and chloridation of Fe-2.25Cr$1 \mathrm{Mo}$ at $773 \mathrm{~K}$ and $\mathrm{Fe}-25 \mathrm{Cr}-20 \mathrm{Ni}-\mathrm{Nb}$ at $973 \mathrm{~K}$ have been studied in $\mathrm{He}-\mathrm{O}_{2}-\mathrm{H}_{2} \mathrm{O}-\mathrm{HCl}$ and $\mathrm{N}_{2}$ $\mathrm{H}_{2}-\mathrm{H}_{2} \mathrm{O}-\mathrm{HCl}$ mixtures in short term oxidation tests. The surface of the corroded samples were examined by SEM and AES. The simultaneous attack of $\mathrm{O}_{2}$ and $\mathrm{Cl}_{2}$ leads to the formation of metal oxides and chlorides side by side on the alloy surfaces during the early stage of reaction, although the chlorides are not in stable equilibrium with the gas phase. After longer exposure times only the thermodynamically stable oxides were detected in the outer scale, however, at the metal/oxide interface chloride layers are still present. The initial simultaneous growth of oxides and chlorides strongly affects the structure and morphology of the subsequently formed oxide scales.
\end{abstract}

\section{Introduction.}

In several technical applications metals and alloys are exposed to oxidizing and chloridizing environments. The presence of $\mathrm{HCl}$ or $\mathrm{Cl}_{2}$ in the gas phase leads to a degradation of protective oxide scales due to formation of volatile reaction products even at relatively low temperatures $(773 \mathrm{~K})$. The steady evaporation of chlorides affects the structure and morphology of the oxides; they always show a porous structure and are badly adherent. The great influence of $\mathrm{Cl}_{2}$ or $\mathrm{HCl}$ on the high temperature corrosion of metals and alloys was studied in many investigations [1-5]. In contrast to simultaneous oxidation-sulfidation [6-8], very few studies have dealt with the transient state of oxidation-chloridation of metals and alloys.

The studies on the transient state of the simultaneous oxidation-sulfidation showed that side-by-side growth of oxides and sulfides occurs in the initial stage of reaction even if only one of these phases can be in stable equilibrium with the gas phase. This leads to the formation of non-protective scales and breakaway corrosion as was often observed.

The study is concerned in aggravated corrosion which will take place in incineration of chlorine containing waste or coal $[10,11]$ - especially if such fuels were used already in the very first run of the plant. The initial, transient state of simultaneous oxidation-chloridation was investigated on one low alloy steel $\mathrm{Fe}-2.25 \mathrm{Cr}-1 \mathrm{Mo}$ which is widely used for heat exchanger tubes in power plants up to $550^{\circ} \mathrm{C}$ and a high alloy steel Fe-25Cr-20Ni-Nb which can be used at higher temperature e.g. for transporting grids. The low alloy steel was exposed at $773 \mathrm{~K}$ and the high alloy steel at $973 \mathrm{~K}$ in short term tests to an oxidizing $\mathrm{He}-\mathrm{O}_{2}-\mathrm{H}_{2} \mathrm{O}-\mathrm{HCl}$ mixture and a "reducing" $\mathrm{N}_{2}-\mathrm{H}_{2}-\mathrm{H}_{2} \mathrm{O}-\mathrm{HCl}$ mixture simulating incineration and gasification atmospheres respective. 


\section{Experimental.}

The chemical compositions of the steels are listed in table I. Short term oxidation tests were performed in a $\mathrm{He}-\mathrm{O}_{2}-\mathrm{H}_{2} \mathrm{O}-\mathrm{HCl}$ mixture at a high oxygen partial pressure and in a $\mathrm{N}_{2}-\mathrm{H}_{2}$ $\mathrm{H}_{2} \mathrm{O}-\mathrm{HCl}$ mixture at a low oxygen partial pressure. In these gas atmospheres different $p_{\mathrm{O}_{2}}$ and $p_{\mathrm{Cl}_{2}}$ were established according to the following equilibria:

$$
\begin{array}{ll}
2 \mathrm{HCi}+\frac{1}{2} \mathrm{O}_{2}=\mathrm{Cl}_{2}+\mathrm{H}_{2} \mathrm{O} & p_{\mathrm{Cl}_{2}}=K \frac{p_{\mathrm{HCl}_{\mathrm{O}}}^{2} p_{\mathrm{O}_{2}}^{1 / 2}}{p_{\mathrm{H}_{2} \mathrm{O}}} \\
\mathrm{H}_{2} \mathrm{O}=\mathrm{H}_{2}+\frac{1}{2} \mathrm{O}_{2} & p_{\mathrm{O}_{2}}=\left(K \frac{p_{\mathrm{H}_{2} \mathrm{O}}}{p_{\mathrm{H}_{2}}}\right)^{2}
\end{array}
$$

The oxygen and chlorine pressures at $773 \mathrm{~K}$ and $973 \mathrm{~K}$ are summarized in table II.

The condensed phases which can be in stable equilibrium with the gas phase under these conditions can be seen from the thermodynamic stability diagrams for $\mathrm{Fe}-\mathrm{O}-\mathrm{Cl}$ at $773 \mathrm{~K}$ (Fig. 1) and for $\mathrm{M}-\mathrm{O}-\mathrm{Cl}(\mathrm{M}=\mathrm{Fe}, \mathrm{Cr}, \mathrm{Ni})$ at $973 \mathrm{~K}$ (Fig. 2) [9]. Under the experimental conditions the oxides are the only stable condensed phases in thermodynamic equilibrium with the gas atmosphere, but the formation pressure of the condensed chlorides is also exceeded.

The oxidized samples were examined after corrosion by scanning electron microscopy (SEM) with energy dispersive X-ray analysis (EDAX) and Auger electron spectroscopy (AES).

Table I. - Chemical composition of investigated iron based alloys (in wt \%).

\begin{tabular}{|c|c|c|c|c|c|}
\hline & $\mathrm{Fe}$ & $\mathrm{Cr}$ & $\mathrm{Ni}$ & $\mathrm{Mo}$ & $\mathrm{Nb}$ \\
\hline $\mathrm{Fe}-2.25 \mathrm{Cr}-1 \mathrm{Mo}$ & $\mathrm{Bal}$ & 2.21 & - & 0.91 & - \\
$\mathrm{Fe}-25 \mathrm{Cr}-20 \mathrm{Ni}-\mathrm{Nb}$ & $\mathrm{Bal}$ & 25.6 & 20.5 & - & 0.1 \\
\hline
\end{tabular}

Table II. - Compositions of the gas mixtures.

\begin{tabular}{|c||c|c|c|c|}
\hline \multirow{2}{*}{$\mathrm{T}[\mathrm{K}]$} & \multicolumn{2}{|c|}{$\mathrm{He}-\mathrm{O}_{2}-\mathrm{H}_{2} \mathrm{O}-\mathrm{HCl}$} & \multicolumn{2}{c|}{$\left.\mathrm{N}_{2}-\mathrm{H}_{2}-\mathrm{H}_{2} \mathrm{O}-\mathrm{HC}\right]$} \\
\hline & $\log \mathrm{p}_{2}$ & $\log \mathrm{p}_{\mathrm{Cl}}$ & $\log \mathrm{p}_{\mathrm{O}_{2}}$ & $\log \mathrm{p}_{\mathrm{Cl}}$ \\
& {$[$ bar] } & {$[$ bar] } & {$[$ bar] } & {$[$ bar] } \\
\hline 773 & -1.71 & -3.46 & -27.9 & -16.55 \\
973 & -1.71 & -4.28 & -21.0 & -13.93 \\
\hline
\end{tabular}




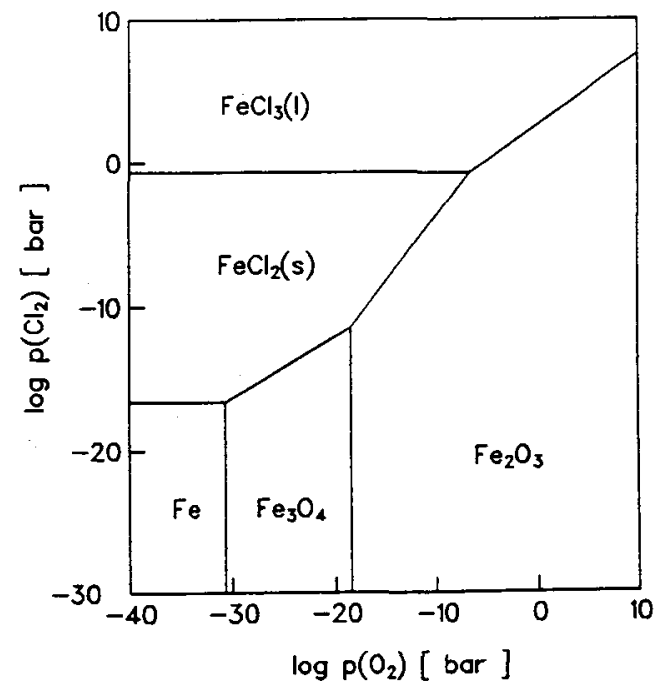

Fig. 1. - Thermodynamic stability diagram of the system $\mathrm{Fe}-\mathrm{O}-\mathrm{Cl}$ at $773 \mathrm{~K}$.

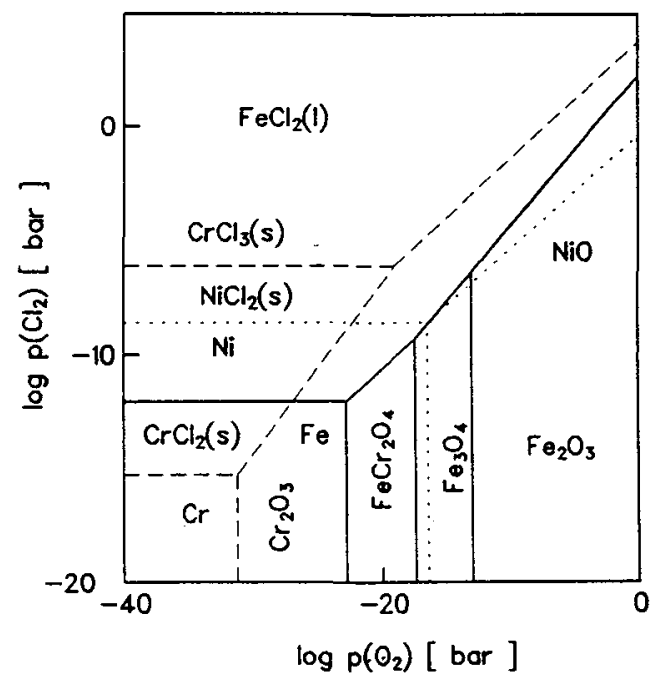

Fig. 2. - Thermodynamic stability diagram of the system $\mathrm{M}-\mathrm{O}-\mathrm{Cl}$ at $973 \mathrm{~K}(\mathrm{M}=\mathrm{Fe}, \mathrm{Cr}, \mathrm{Ni})$.

\section{Results.}

Fe-2.25Cr-1 Mo. - When a blank metallic alloy surface is exposed to a corrosive gas atmosphere at high temperatures each phase can be formed, whose formation pressure is exceeded in the gas phase [7,12-14]. Therefore during the transient state for Fe-2.25Cr-1Mo at $773 \mathrm{~K}$ not only $\mathrm{Fe}_{2} \mathrm{O}_{3}$ formation was expected but also $\mathrm{Fe}_{3} \mathrm{O}_{4}$ and $\mathrm{FeCl}_{2}$ (s) formation. 


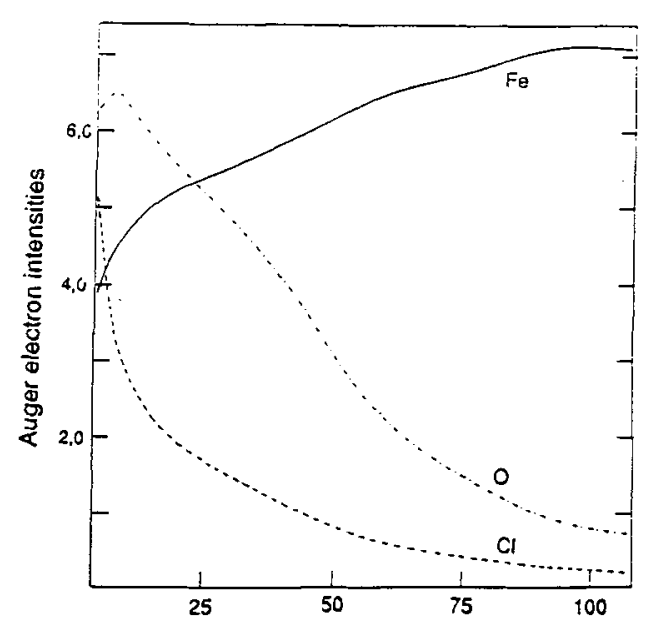

a)

sputter time [ $\mathrm{min}$ ]

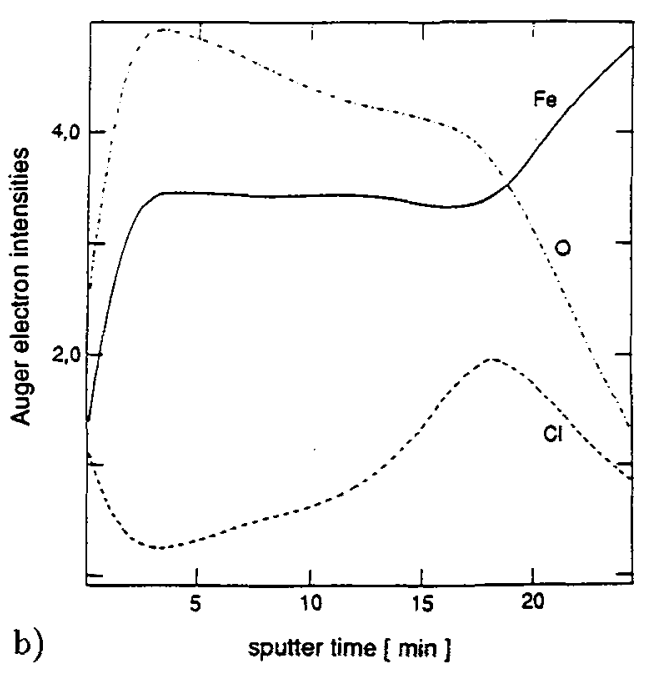

b)

Fig. 3. - a) AES sputter profile of $\mathrm{Fe}-2.25 \mathrm{Cr}-1 \mathrm{Mo}$ after 1 min oxidation in $\mathrm{He}-\mathrm{O}_{2}-\mathrm{H}_{2} \mathrm{O}-\mathrm{HCl}$ at $773 \mathrm{~K}$; b) AES sputter profile of $\mathrm{Fe}-2.25 \mathrm{Cr}-1 \mathrm{Mo}$ after $10 \mathrm{~min}$ oxidation in $\mathrm{He}-\mathrm{O}_{2}-\mathrm{H}_{2} \mathrm{O}-\mathrm{HCl}$ at $773 \mathrm{~K}$.
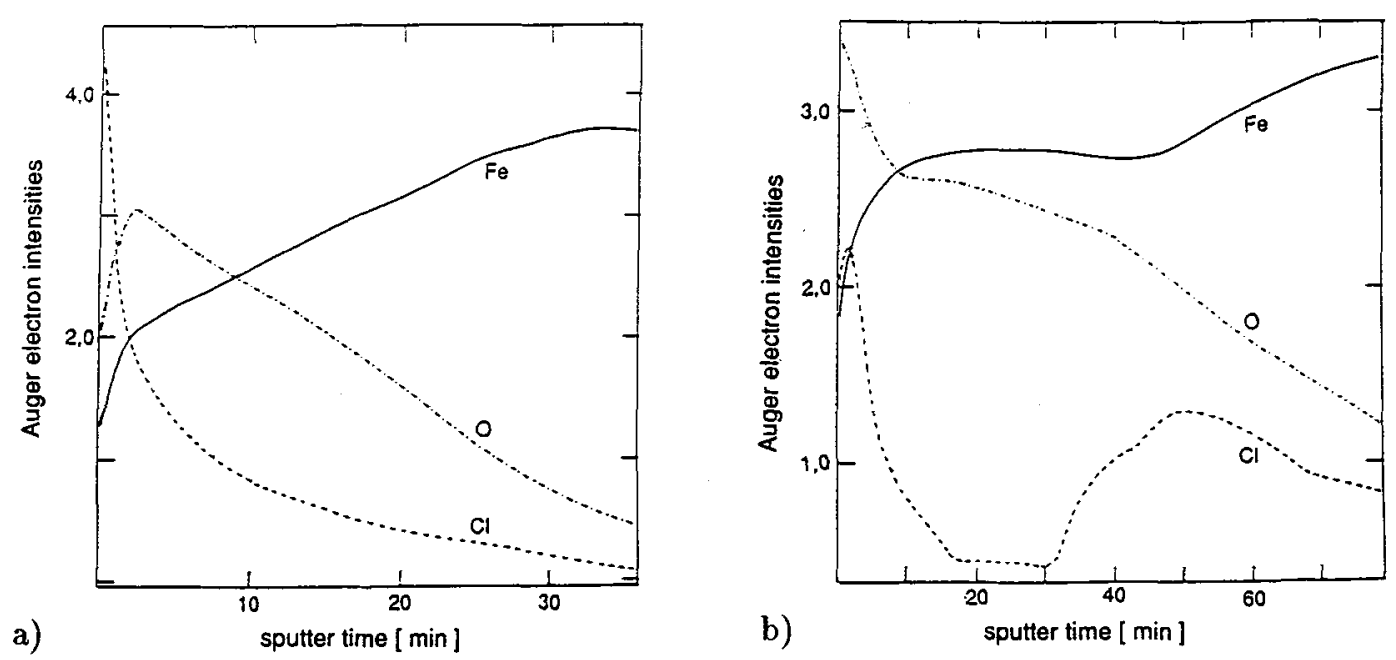

Fig. 4. - a) AES sputter profile of $\mathrm{Fe}-2.25 \mathrm{Cr}-1 \mathrm{Mo}$ after 1 min oxidation in $\mathrm{N}_{2}-\mathrm{H}_{2}-\mathrm{H}_{2} \mathrm{O}-\mathrm{HCl}$ at $773 \mathrm{~K}$; b) AES sputter profile of Fe-2.25Cr-1Mo after 10 min oxidation in $\mathrm{N}_{2}-\mathrm{H}_{2}-\mathrm{H}_{2} \mathrm{O}-\mathrm{HCl}$ at $773 \mathrm{~K}$.

In figures 3 and 4 AES sputter profiles are shown obtained on Fe-2.25Cr-1 Mo samples after 1 and 10 min exposure to the $\mathrm{He}_{2}-\mathrm{O}_{2}-\mathrm{H}_{2} \mathrm{O}-\mathrm{HCl}$ and $\mathrm{N}_{2}-\mathrm{H}_{2}-\mathrm{H}_{2} \mathrm{O}-\mathrm{HCl}$ gas mixtures at $773 \mathrm{~K}$. In both gas atmospheres with high and low oxygen partial pressures, after I min reaction, iron oxides and chloride were detected on the surface of the sample, although $\mathrm{FeCl}_{2}(\mathrm{~s})$ is not in stable equilibrium with the gas phase. In this early stage of oxidation the iron chloride is in equilibrium with the metal phase and the iron activity $\left(a_{\mathrm{Fe}}\right)$ on the scale surface is high.

After 10 minutes of oxidation, only iron oxide was detected on the sample. Upon taking 
a sputter profile a significant chlorine enrichment was observed at the oxide-alloy interface. This shows that the chloride was overgrown by the thermodynamically stable oxide and that equilibrium with the gas phase was established at the gas/oxide interface, beneath the oxide layer the iron chloride remained. There the oxygen pressure is reduced. However, $\mathrm{FeCl}_{2}(\mathrm{~s})$ is only stable at a low $p_{\mathrm{O}_{2}}$, if the chlorine pressure is sufficiently high. During the early stage of reaction oxides and chlorides grow simultaneously, making the formation of a dense, protective oxide scale unlikely. The morphology of the porous oxide scale is shown in figure $5 \mathrm{~b}$ and is different when compared with the scale formed in a HCl-free atmosphere (Fig. 5a). Through such a scale, $\mathrm{Cl}_{2}$ and $\mathrm{HCl}$ have easy access to the underlying substrate, thus stabilizing the ferrous chloride. With an increasing scale thickness resulting from oxidation, the iron activity $\left(a_{\mathrm{Fe}}\right)$ decreases on the scale surface. If $a_{\mathrm{Fe}}$ at the surface becomes too low to form the chloride, the oxide can overgrow the chloride and subsequently $\mathrm{FeCl}_{2}$ is present at the metal/oxide interface.

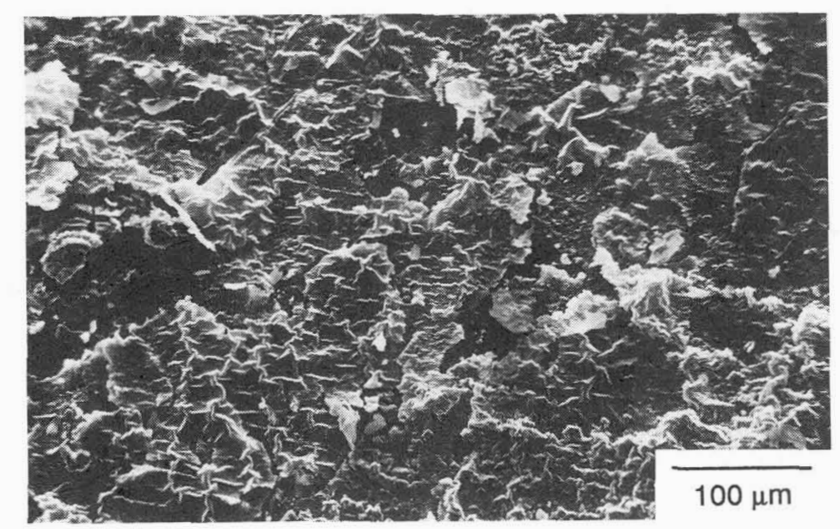

a)

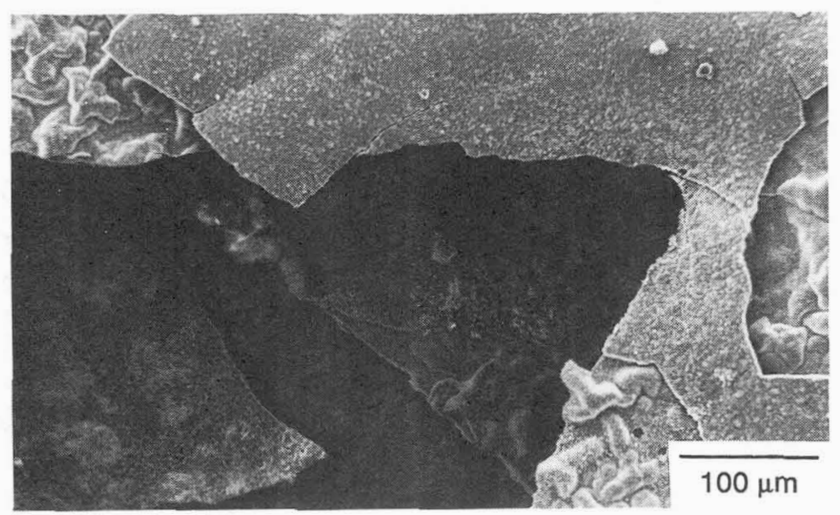

b)

Fig. 5. - SEM micrographs of Fe-2.25Cr-1Mo after oxidation at $773 \mathrm{~K}$ in: a) $\mathrm{He}-\mathrm{O}_{2}$; b) $\mathrm{He}-\mathrm{O}_{2}-\mathrm{H}_{2} \mathrm{O}-$ HCl. 
Fe-25Cr-20Ni-Nb. - In figures 6 and 7, AES sputter profiles are shown taken on Fe-25Cr$20 \mathrm{Ni}-\mathrm{Nb}$ samples after $\mathrm{l}$ and 10 min oxidation in $\mathrm{He}-\mathrm{O}_{2}-\mathrm{H}_{2} \mathrm{O}-\mathrm{HCl}$ and $\mathrm{N}_{2}-\mathrm{H}_{2}-\mathrm{H}_{2} \mathrm{O}-\mathrm{HCl}$ at $973 \mathrm{~K}$ are shown. From the profiles, after $1 \mathrm{~min}$ exposure, can be seen that simultaneous

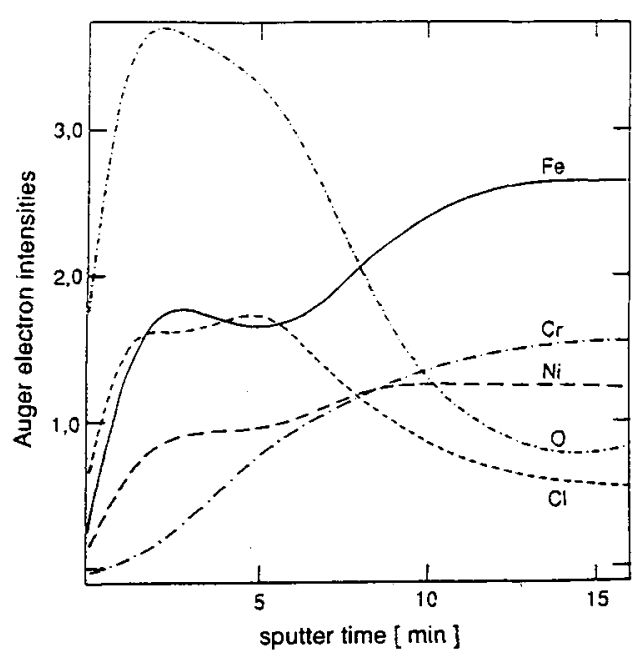

a)

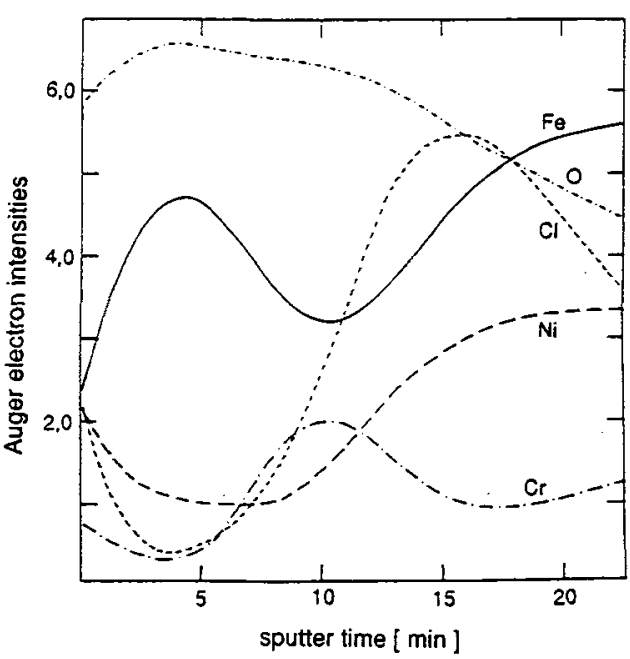

b)

Fig. 6. - a) AES sputter profile of Fe-25Cr-20Ni-Nb after 1 min oxidation in $\mathrm{He}-\mathrm{O}_{2}-\mathrm{H}_{2} \mathrm{O}-\mathrm{HCl}$ at 973

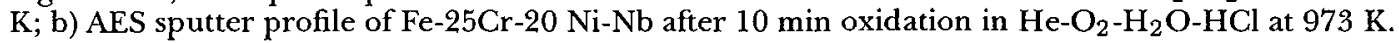

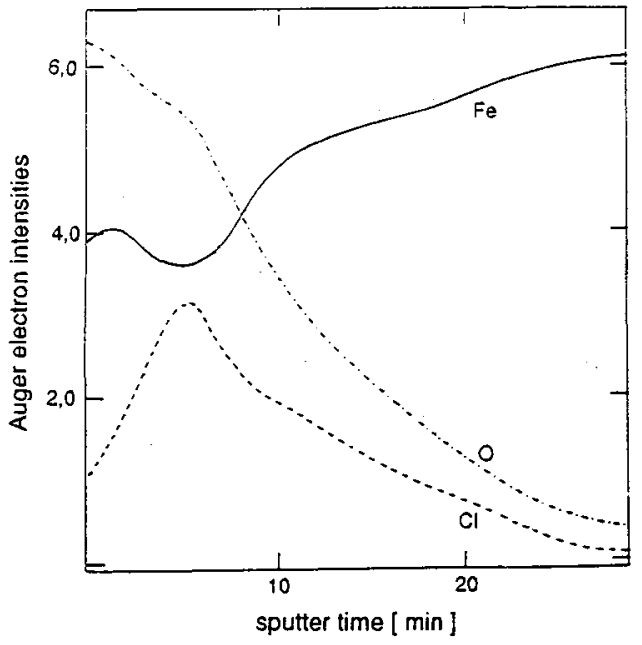

a)

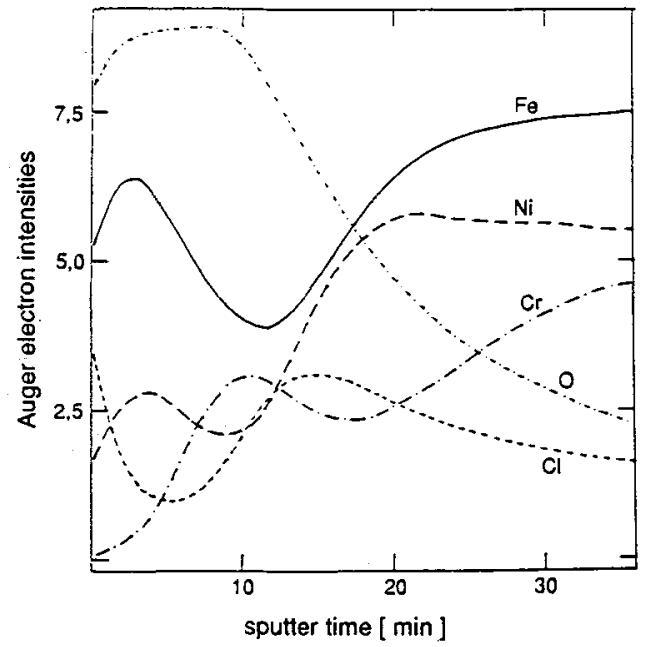

b)

Fig. 7. - a) AES sputter profile of $\mathrm{Fe}-25 \mathrm{Cr}-20 \mathrm{Ni}-\mathrm{Nb}$ after 1 min oxidation in $\mathrm{N}_{2}-\mathrm{H}_{2}-\mathrm{H}_{2} \mathrm{O}-\mathrm{HCl}$ at 973 $\mathrm{K}$; b) AES sputter profile of Fe-25Cr-20 Ni-Nb after 10 min oxidation in $\mathrm{N}_{2}-\mathrm{H}_{2}-\mathrm{H}_{2} \mathrm{O}-\mathrm{HCl}$ at $973 \mathrm{~K}$. 


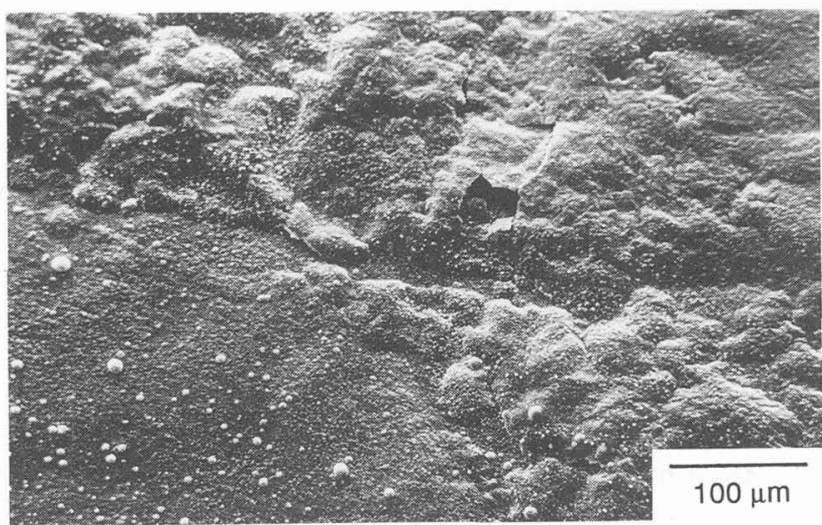

a)

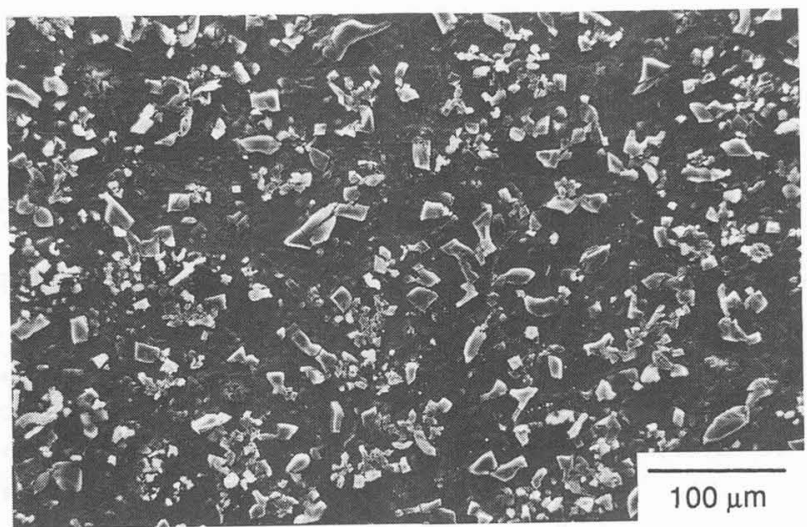

b)

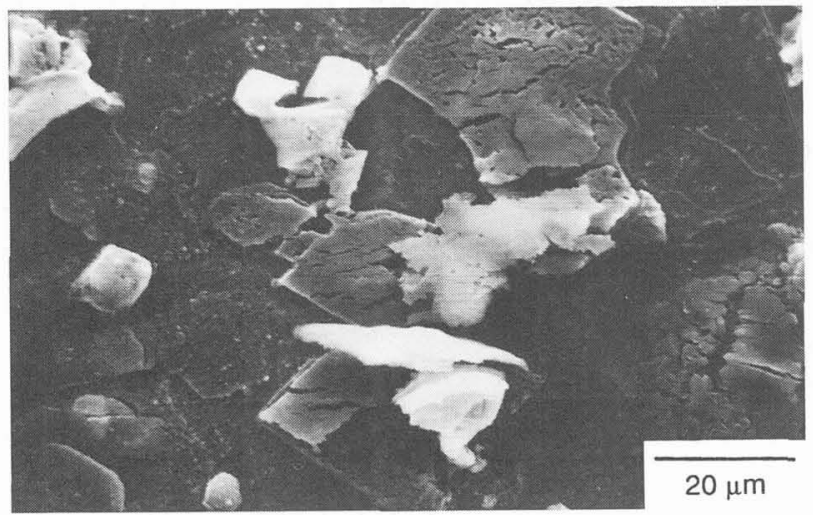

c)

Fig. 8. - SEM micrographs of Fe-25Cr-20Ni-Nb after oxidation at $973 \mathrm{~K}$ in: a) $\mathrm{He}_{2}-\mathrm{O}_{2}$; b) and c) He$\mathrm{O}_{2}-\mathrm{H}_{2} \mathrm{O}-\mathrm{HCl}$. 
growth of oxides and chlorides occurred in both atmospheres on this high alloy steel, although the chloride was not in stable equilibrium with the gas phase. In the early stage of oxidation, the chloride is in equilibrium with the metal phase and the metal activity is high on the surface of the reaction products.

After longer oxidation times the thermodynamically stable oxides have overgrown the chloride phase, and on the scale surface, only oxides could be detected in both gas atmospheres. Beneath the oxide layer, a chloride layer was detected. Also on this high chromium and nickel containing alloy the simultaneous growth of oxides and chlorides leads to the formation of a non-protective, porous oxide scale (Figs. 8a, b, c) different to the scale formed during oxidation in $\mathrm{He}-\mathrm{O}_{2}$. As mentioned previously, this allows $\mathrm{Cl}_{2}$ and $\mathrm{HCl}$ species easy access to the underlying alloy substrate thus stabilizing the chloride phase beneath the oxide.

With increasing scale thickness, the metal activity $\left(a_{\mathrm{Me}}\right)$ on the surface decreases. If $a_{\mathrm{Me}}$ becomes too low, no chloride forms and the oxides overgrow the chloride and subsequently the chloride is present at the metal/oxide interface.

\section{Conclusions.}

The transient state of simultaneous oxidation-chloridation of Fe-2.25Cr-1 Mo at $773 \mathrm{~K}$ and Fe-25Cr-20Ni- $\mathrm{Nb}$ at $973 \mathrm{~K}$ has been examined in $\mathrm{He}-\mathrm{O}_{2}-\mathrm{H}_{2} \mathrm{O}-\mathrm{HCl}$ and $\mathrm{N}_{2}-\mathrm{H}_{2}-\mathrm{H}_{2} \mathrm{O}-\mathrm{HCl}$ mixtures in short term corrosion tests.

Upon short time exposure the simultaneous growth of oxide and chloride was observed independent of the alloy composition, both in the atmosphere at a high $p_{\mathrm{O}_{2}}$ and a low $p_{\mathrm{O}_{2}}$, although the chloride is not in stable equilibrium with the gas phase. After longer exposure times only the thermodynamic stable oxides were detected on the surface of the scales. However, at the metal/oxide interface, where the oxygen pressure is sufficiently low, a chloride layer is still present. The initial simultaneous growth of oxides and chlorides and the subsequent formation of a chloride layer at the metal/oxide interface occurs in both the oxidizing and the more reducing atmosphere on the two different alloys and strongly affects the structure and morphology of the oxide layer deteriorating the protective function of the scale as demonstrated by SEM.

\section{Acknowledgements.}

This study was supported by the Bundesminister für Forschung und Technologie (BMFT).

\section{References}

[1] ElLiott P., MarSh G., Corros. Sci. 24 (1984) 397.

[2] MCNallan M.J., Liang W.W., Kim S.H., Kang C.T., High Temp. Corrosion, R.A. Rapp Ed. (San Diego 1981) (NACE, Houston, 1983).

[3] JOHNSON J.B., NichOlls J.R., HURST R.C., HANCOCK P., Corros. Sci 18 (1978) 527.

[4] BRAMHOFF D., GRABKE H.J., SCHMidT H.P., Werkst. Korros. 40 (1989) 642.

[5] BRAMHOfF D., GRABKe H.J., ReESE E., SCHMidT H.P., Werkst. Korros. 41 (1990) 303.

[6] LobNig R.E., GRabke H.J., Corros. Sci 30 (1990) 1045. 
[7] Hussey R., Papaiacovou P., Grabke H.J., in Proceed. 8e. Congress Europeen de Corrosion (Nice, Nov. 19-21, 1985).

[8] PERkins R.A., Proceedings of the conference on corrosion/erosion of coal conversion materials, A.V. Levy Ed. (NACE, Jan. 1979) p. 351.

[9] BARIN I., KNACKE O., Thermochemical Properties of Inorganic Substances (Springer Verlag, Berlin, 1973).

[10] KRAUSE H.H., Incinerating municipal and industrial waste, R.W. Bryers Ed. (Hemisphere Publishing Corporation, New York, 1990).

[11] BanerJeE D.A., Stringer J.E., Chlorine in Coal (Elsevier Science Publishers, NorthHolland, 1991).

[12] Hussey R.J., Papaiacovou P., Grabke H.J., Werkst. Korros. 37 (1986) 578.

[13] GRABKE H.J., High Temperature Materials Corrosion in Coal Gasification Atmospheres, J.F. Norton Ed. (Elsevier Applied Science, Barking, U.K., 1984).

[14] Rahmel A., Werkst. Korros. 21 (1970) 925. 